\title{
The Formation of Islamic Hermeneutics: How Sunni Legal Theorists Imagined a Revealed Law
}

David R. Vishanoff

New Haven, CT: American Oriental Society, 2011. 344 pages.

David Vishanoff's The Formation of Islamic Hermeneutics is a significant contribution to the study of Islamic legal theory and legal hermeneutics. Vishanoff's main objective is to examine how Sunni legal hermeneutics became a systematic and institutional discipline. For this purpose, he strives to restore the reception and development of al-Shafi'i's (d. 820) legal hermeneutics dur- 
ing the pre-classical period (ninth to eleventh centuries). He presents the imam as the first scholar to have codified an Islamic legal theory and reads him in light of four hermeneutical models: the Zahiri, Mu'tazili, Ash'ari and, what he calls, a law-oriented model. The book is organized into seven chapters, five of which are devoted to al-Shafi' $i$ 's hermeneutics and the four responses to it. Chapter 1 and 7, respectively, serve as analytic introduction and conclusion.

The most authoritative source investigated by the author, and to which Chapter 2 is devoted, is al-Shafi'i's Al-Risālah fì Ușül al-Figh. Central to this text is al-Shafi'i's argument that a system of law can and should be inferred from revelation: the Qur'an and Sunnah. The Risālah, Vishanoff confirms, is the first work to have raised a consequential hermeneutical question in the Islamic legal theory: How does one reconcile revealed texts with legal rules? Al-Shafi'i's solution, one that places the Qur'an's equivocalness or linguistic ambiguity at the centre of its argument, was one of the most debated legal themes at the time; a deliberation that has largely contributed to the formation of classical ușül al-fiqh.

The first two "doctrinal" reactions to al-Shafi' $i$ that Vishanoff reconstructs, those of the Zahiris (chapter 3) and the Basra Mu'tazilis (chapter 4), subject his hermeneutics to serious confinements. Although the Zahiris insisted that law must find legitimacy in revelation, they refused to grant jurists the hermeneutical tools they require to clarify the scripture's equivocal language. This is generally explained, as the author affirms, by the Zahiri emphasis on a literal reading of the Qur'an on the grounds that its language contained no ambiguities. On the other hand, the Basra Mu'tazilis generated two different epistemological responses: They allowed creative interpretation at the theological level, but restricted the practice of interpretation in the legal realm.

The other two responses came from the Ash'ari school of theology (chapter 5) and what Vishanoff calls the "law-oriented paradigm" (chapter 6). The Ash'aris are held to have accepted Shafi' $i$ hermeneutics almost without any reservation, for they conceived of the revealed text as a system that necessitates further clarification in order to navigate and infer God's commands. The law-oriented theorists, however, put al-Shafi' i's approach under novel and radical tests because they were less interested in the theological debate of legal hermeneutics, and more concerned with law proper. Vishanoff attributes two contributions to this model: Its adherents granted more power to the interpreter to deduce legal meaning from the scripture and thus rendered the revealed text flexible enough to modify its meaning, as necessary, to connect it to the larger legal system. 
That Vishanoff's study is a serious endeavor in the field of Islamic legal theory can hardly be disputed. However, minor conceptual flaws and structural inconsistencies need attention. At the conceptual level, most problematic perhaps is the vagueness of the word imagine. Throughout the book, the author repeatedly stresses the act of "imagining" the law, but never explains how this is accomplished. At times he calls interpreters "imagined interpreters" (pp. 46) and inferred laws "imagined abstractions" (p. 9). It is highly unlikely that the legal theorists drawn upon in this book thought of what they did as imagining (takhayyul) the law. Takhayyul is one of few concepts that received remarkably meticulous treatment in the Arabic medieval circles, whether in literature, philosophy (especially in Ibn Sina's psychology) or mysticism (Ibn 'Arabi). But it is probable that the author simply refers to the act of conceiving of the law and/or desires to stress its historicity and maybe the historicity of revelation as well. In either case, such tremendous emphasis on the act of imagining the law requires at least some elaboration to avoid confusion.

Few occasional translation inaccuracies also appear to be a problem. For example, majāz is oddly rendered as "transgression" instead of "figure of speech," "metaphor" or "allegory." Vishanoff's plea to the reader to think of transgression "without its strong negative connotation" (p. 21) already implies that it is an imprecise equivalent. The author rarely explains why and when he diverges from the conventional translation of certain legal terms, and this may be one reason why some of his translations seem inappropriate. In terms of structure, a specialist reader may be troubled by how a great deal of concepts and technical legal terms is not accompanied with their original Arabic transliterated term when introduced for the first time. For instance, we read "legal theory" on page xiii, but only learn its Arabic equivalent, namely uṣūl al-fiqh, eleven pages later (p. 2). Other concepts, such as ambiguity and clarity, are treated in the same way. This problem recurs particularly in the preface and chapter 1, which makes them somewhat dense and difficult to navigate.

Generally, Vishanoff's Formation is a decent work and his overall command of Arabic can not be derogated. His discussion of the role of al-Shafi'i's fiqh, its formative debate and the rise of the law-oriented model is a well maneuvered exercise. Regardless of its minor weaknesses, some of which the author has already anticipated, this work is an valuable contribution to the field of Islamic legal hermeneutics. 